\title{
THE WORLD OF WALTHER NERNST
}

The Rise and Fall of German Science 


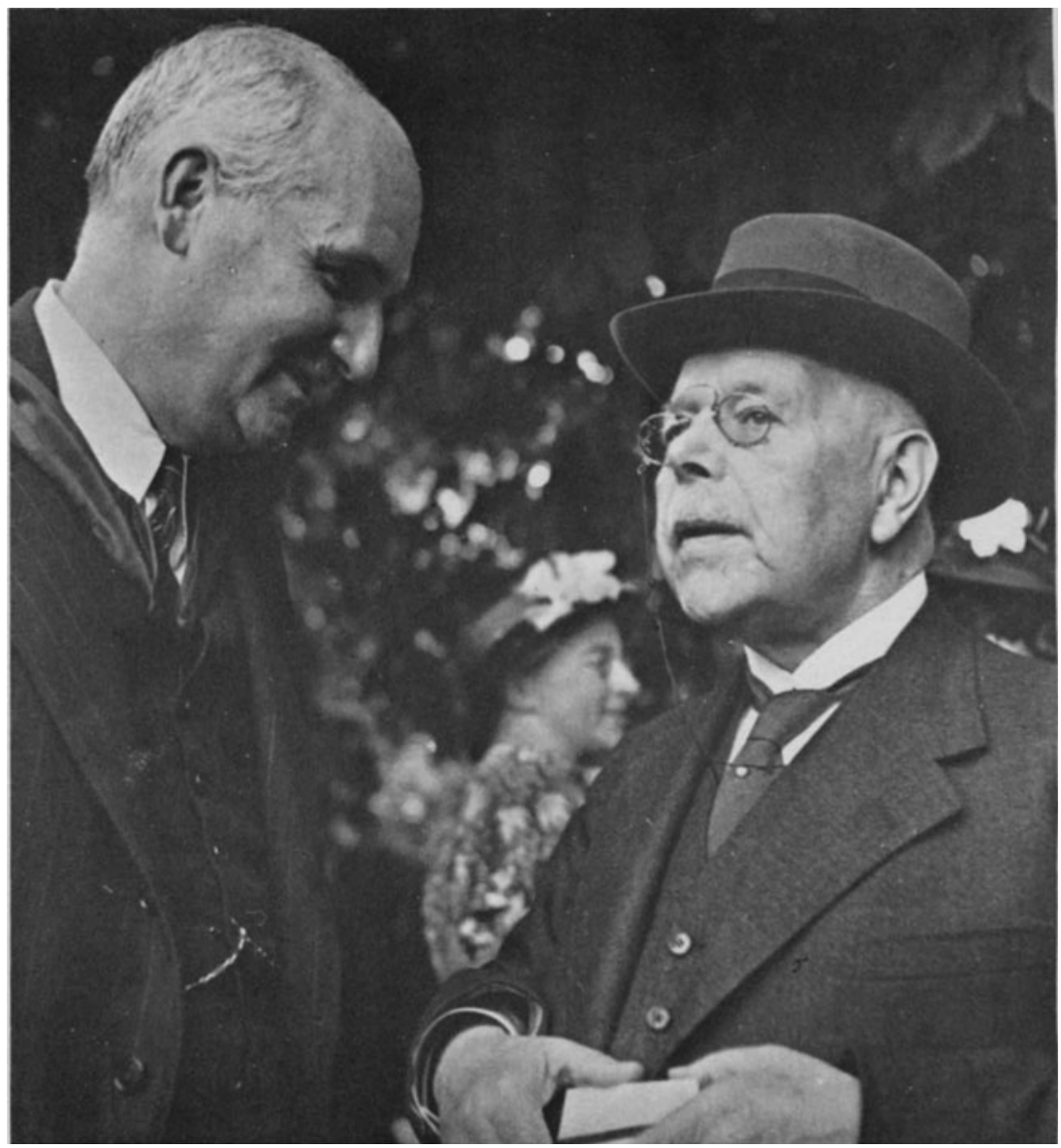

Nernst and Lindemann in Oxford, 1937. 


\section{THE WORLD OF WALTHER NERNST}

The Rise and Fall of German Science K. MENDELSSOHN, F.R.S. 
ISBN 978-1-349-01918-2 ISBN 978-1-349-01916-8 (eBook)

DOI 10.1007/978-1-349-01916-8

(C) K. Mendelssohn 1973

Softcover reprint of the hardcover 1st edition 1973 978-0-333-14895-2

All rights reserved. No part of this publication

may be reproduced or transmitted, in any form or by any means, without permission.

First published 1973

THE MAGMILLAN PRESS LTD

London and Basingstoke

Associated companies in New Tork Melbourne

Dublin Johannesburg and Madras

SBN 333 I4895 9 
Dedicated to the Memory of

F. A. Lindemann, Viscount Cherwell 


\section{Contents}

Preface viii

I. Prologue I

2. Founder Years 8

3. A Place in the Sun 29

4. The Summit 51

5. Glorious Times $\quad 77$

6. Revolution 94

7. The New Babylon 1 I

8. Heads Will Roll 144

9. Epilogue 164

$\begin{array}{ll}\text { Index } & 185\end{array}$ 


\section{Preface}

The idea for this book first suggested itself when, almost ten years ago, the Humboldt University in East Berlin asked me to deliver a memorial address on the occasion of the centenary of Nernst's birth. Since then I have been helped by discussions with my colleagues, too numerous to be mentioned individually, in trying to recall events of the past. I am particularly grateful to Nernst's surviving daughters, Mrs Edith von Zanthier and Mrs Angela Hahn, for a great deal of information about their parents and ancestors which they gave me both verbatim and in writing, and for making available to me notes made by Emma Nernst. They also supplied the material for many of the plates. Other illustrations were kindly provided by Lady Simon, Mrs L. Meitner-Graff, Professors G. Born, J. Eggert, O. R. Frisch, W. Haberditzl, W. Heisenberg and I. Prigogine, and Drs C. Bosch and F. L. Haber.

Oxford

K. $M$.

March 1973 